\title{
PENGARUH PENAMBAHAN WORTEL TERHADAP TINGKAT KESUKAAN NUGGET AYAM
}

\author{
SUSANTI, A. A. R. ${ }^{1}$, L. A. HENDRAWATI ${ }^{2}$, DAN S. LIKAH ${ }^{3}$ \\ ${ }^{1}$ Mahasiswa Program Studi Penyuluhan Peternakan dan Kesejahteraan Hewan \\ 2,3Program Studi Penyuluhan Peternakan dan Kesejahteraan Hewan, Polbangtan Malang, \\ e-mail: audiaayurs@gmail.com
}

\begin{abstract}
ABSTRAK
Kegiatan penelitian ini bertujuan untuk mengetahui pengaruh persentase penambahan wortel terhadap tingkat kesukaan (warna, bau, rasa, tekstur) nugget ayam. Penelitian ini dilaksanakan di KWT Sejahtera (30 orang), Desa Jeruk Sok Sok, Kecamatan Binakal, Kabupaten Bondowoso.pada bulan Juni 2020. Metode penelitian menggunakan metode rancangan acak lengkap dengan 3 kali perlakuan: penambahan wortel P1 (15\%), P2 (25\%), P3 (35\%) dan 6 kali ulangan. Analisis data menggunakan Uji Friedman dan Uji Lanjut Indeks Efektivitas de Garmo. Hasil penelitian menunjukkan terdapat perbedaan nyata $(\mathrm{P}<0,05)$ pengaruh persentase penambahan wortel terhadap tingkat kesukaan warna, bau dan tekstur nugget ayam dan tidak terdapat perbedaan nyata $(\mathrm{P}>0,05)$ pengaruh presentase penambahan wortel terhadap tingkat kesukaan rasa nugget ayam. Pada uji lanjut didapatkan bahwa perlakuan terbaik adalah perlakuan ketiga (35\%) dengan skor NP 0,93. Berdasarkan hasil penelitian, dapat disimpulkan bahwa penambahan wortel sampai $35 \%$ pada aspek rasa, bau, tekstur nugget ayam masih bisa diterima dan disukai konsumen.
\end{abstract}

Kata kunci: nugget, wortel, warna, bau, rasa, tekstur

\section{THE EFFECT OF ADDITION CARROT ON THE LEVEL OF PREFERENCE CHICKEN NUGGETS}

\begin{abstract}
This research activity aims to determine the effect of the percentage of adding carrots on the level of preference (color, smell, taste, texture) of chicken nuggets. This research was conducted at KWT Sejahtera (30 people), Jeruk Sok Sok Village, Binakal District, Bondowoso Regency in June 2020. The research method used was a completely randomized design method with 3 treatments of adding carrots P1 (15\%), P2 (25\% ), P3 (35\%) and 6 replicates. Data analysis used Friedman Test and de Garmo Effectiveness Index Advanced Test. The results showed that there was a significant difference $(\mathrm{P}<0.05)$ in the effect of the percentage of adding carrots on the level of preference for color, smell and texture of chicken nuggets and there was no significant difference (P>0.05) in the effect of the percentage of adding carrots on the level of taste preference for chicken nuggets. In further test it was found that the best treatment was the third treatment (35\%) with an NP score of 0.93 . Based on the research results, it can be concluded that the addition of carrots up to $35 \%$ in terms of taste, smell, and texture of chicken nuggets is still acceptable and preferred by consumers.
\end{abstract}

Key words: nugget, carrots, color, smell, taste, texture

\section{PENDAHULUAN}

Daging ayam merupakan komponen utama dari karkas ayam, yang terdiri dari kumpulan jaringan otot. Karakteristik dari daging ayam yaitu memiliki rasa lezat, tekstur yang empuk dan kandungan gizi yang tinggi untuk tubuh. Menurut penelitian Sugianto dan Harjanto (2006) daging ayam merupakan bahan pangan yang tersusun dari komponen protein, lemak, karbohidrat, vitamin, air, mineral dan pigmen. Oleh karena dari itu daging ayam sangat dicari dan digemari oleh masyarakat. Biasanya ibu-ibu rumah tangga 
mengolah daging ayam menjadi berbagai olahan, salah satunya adalah nugget ayam. Nugget ayam merupakan salah satu makanan siap saji yang sangat disukai oleh semua kalangan terutama anak-anak karena rasanya yang lezat, bentuknya yang menarik dan mudah digenggam. Mengkonsumsi nugget ayam dapat memenuhi kebutuhan protein hewani dalam tubuh, sehingga sangat baik untuk gizi anak. Menurut Litbang Pertanian (2017), anak-anak memerlukan protein yang lebih banyak daripada orang dewasa karena mereka masih mengalami masa pertumbuhan.

Di Kecamatan Binakal konsumsi protein hewani pada anak anak cukup terpenuhi. Didiukung penelitian Widiarti dan Santosa (2017) konsumsi protein di Kabupaten Bondowoso cukup baik dimana mendekati standar yang ditetapkan Kementerian Negara Urusan Pangan RI yaitu 45 gram per kapita per hari, lebih baik dibandingkan Kabupaten Lumajang dan Malang. Seringkali konsumsi protein hewani ini tidak diimbangi dengan mengkonsumsi sayur sayuran sebagai sumber serat dan vitamin yang diperlukan tubuh. Permasalahan terbesar yang biasa ditemui, dimana hampir semua anakanak bahkan remaja tidak menyukai sayuran, karena diniliai memiliki rasa yang tidak enak dengan cenderung pahit, dan warna yang kurang menarik. Hal ini didukung oleh pernyataan Depkes RI (2017) menunjukkan konsumsi sayur di Indonesia mengalami penurunan. Hal ini karena sayur merupakan makanan yang paling ditolak oleh anak-anak karena rasanya yang pahit.

Perlu adanya alternatif solusi agar konsumsi sayur pada anak-anak dapat meningkat yaitu dengan mengkombinasikan nugget ayam dengan sayuran. Tetapi anak-anak cenderung menyukai makanan manis, untuk itu perlu diakali dengan penambahan sayuran manis dan warna yang menarik. Wortel merupakan sayuran yang memiliki kriteria yang memiliki rasa manis dan warna yang menarik dibandingkan sayuran lain seperti brokoli, sawi, dan sayuran hijau lainnya. Dengan pertimbangan tersebut, wortel sangat cocok jika ditambahkan dalam olahan nugget ayam serta dapat memenuhi dan meningkatkan kebutuhan gizi pada tubuh. Didukung oleh penelitan Gaman dan Sherington (1992) wortel merupakan sumber serat dan vitamin, dimana memiliki kandungan bioaktif antara lain betakaroten, karotenoid, dan antioksidan, sehingga dapat memberikan pengaruh positif pada tubuh.

Dalam penambahan wortel pada nugget ayam perlu mempertimbangkan proporsi yang tepat agar produk yang dihasilkan seimbang dari segi rasa, warna, aroma, dan tekstur yaitu dengan melakukan uji organoleptik. Sehingga dapat menghasilkan produk yang dapat diterima oleh semua kalangan masyarakat. Menurut Lestari et al. (2013) mutu organoleptik tidak bisa diabaikan dalam pengembangan produk karena seberapa tinggi dan bagus nilai gizi ataupun manfaat suatu produk makanan, jika rasanya tidak enak, tentunya kemanfaatannya tidak dapat dinikmati oleh konsumen.

Tujuan penelitian ini adalah untuk mengetahui pengaruh presentase penambahan wortel terhadap tingkat kesukaan (warna, bau, rasa, tekstur) nugget ayam.

\section{METODE PENELITIAN}

\section{Lokasi dan Waktu}

Kegiatan penelitian ini dilaksanakan di Desa Jeruk Sok Sok, Kecamatan Binakal, Kabupaten Bondowoso. Waktu penelitian dilaksanakan pada bulan Juni 2020.

\section{Metode Penelitian}

Penelitian menggunakan rancangan acak lengkap (RAL RAL), dengan 3 kali perlakuan: P1 (penambahan wortel $15 \%$ dalam $320 \mathrm{~g}$ daging), P2 (penambahan wortel $25 \%$ dalam $320 \mathrm{~g}$ daging), $\mathrm{P}_{3}$ (penambahan wortel 35\% dalam 320 g daging) dan 6 kali ulangan. Parameter yang diamati dalam penelitian ini adalah tingkat kesukaan konsumen (uji organoleptik) terhadap warna, bau, rasa dan tekstur nugget ayam.

Pengujian organoleptik menggunakan panelis tidak terlatih sebanyak 30 orang terdiri dari pelajar dan ibu rumah tangga. Lembar pengujian organoleptik diisi oleh panelis sesuai dengan skor kesukaan yang tertera yaitu 5 (sangat suka), 4 (suka), 3 (cukup), 2 (tidak suka), 1 (sangat tidak suka). Analisis data menggunakan Uji Friedman dengan selang kepercayaan $5 \%$ (menggunakan SPSS 20.0), dan untuk menentukan perlakuan terbaik menggunakan uji lanjut Indeks Efektivitas de Garmo (perhitungan manual).

Prosedur pembuatan nugget ayam sebagai berikut:

1. Bahan yang digunakan meliputi daging ayam 320 $\mathrm{g}$, tepung tapioka $30 \mathrm{~g}$, terigu $30 \mathrm{~g}$, susu dancow 1 sachet, bawang putih $6 \mathrm{~g}$, bawang merah $3 \mathrm{~g}$, garam $6 \mathrm{~g}$, merica $4 \mathrm{~g}$, penyedap $2 \mathrm{~g}$, telur 1 butir, gula pasir $3,5 \mathrm{~g}$, tepung roti $25 \mathrm{~g}$, minyak goreng $200 \mathrm{ml}$, dan wortel sesuai perlakuan.

2. Cara pembuatan nugget ayam wortel meliputi penghalusan daging ayam beserta bumbu, pencampuran daging ayam dengan bumbu dan wortel sesuai dengan perlakuan, pemindahan adonan ke dalam loyang dilanjutkan pengukusan selama \pm 30 menit, lalu pemotongan nugget dengan dilumuri tepung panir, terakhir digoreng dalam minyak yang panas.

\section{HASIL DAN PEMBAHASAN}

Tabel 1 menunjukkan bahwa terdapat perbedaan nyata $(\mathrm{P}<0,05)$ pengaruh persentase penambahan wortel terhadap tingkat kesukaan warna, bau dan 
terkstur nugget ayam yang dihasilkan. Sedangkan tidak terdapat perbedaan nyata $(\mathrm{P}>0,05)$ pengaruh persentase penambahan wortel terhadap tingkat kesukaan rasa nugget ayam.

Tabel 1. Hasil uji Friedman parameter organoleptik

\begin{tabular}{cccc}
\hline Parameter & Sig & Asymp. Sig & Keterangan \\
\hline Warna & 0.05 & 0,008 & Ada pengaruh \\
Bau & 0.05 & 0,004 & Ada pengaruh \\
Rasa & 0.05 & 0,141 & Tidak ada pengaruh \\
Tekstur & 0.05 & 0,002 & Ada pengaruh \\
\hline
\end{tabular}

Analisa organoleptik nugget ayam dengan penambahan wortel meliputi: parameter warna nugget ayam dengan penambahan wortel menghasilkan warna yang menarik artinya lebih oranye dibandingkan dengan nugget ayam tanpa penambahan wortel karena dalam wortel mengandung pigmen warna jingga yang dapat membuat warna nugget menjadi menarik. Hasil kajian ini sesuai dengan pernyataan Bhosale et al. (2011), dimana penambahan wortel pada nugget ayam memberikan warna yang lebih baik dan lebih menarik, karena adanya kandungan karotenoid pada wortel.

Pada parameter bau/aroma nugget ayam dengan penambahan wortel menghasilkan, wortel dapat mengurangi bau khas daging ayam tetapi tidak menghilangkan bau khas daging ayam, sehingga bau nugget ayam wortel lebih bervariasi. Hal ini sesuai dengan penelitian Utami et al. (2018) penambahan sayuran pada nugget ayam dapat menutupi bau daging ayam, sehingga kekuatan aroma daging ayam yang dihasilkan semakin berkurang. Didukung Gaman dan Sherrington (1992) menyatakan bahwa ketengikan atau oksidasi dapat dikurangi dengan menyimpan lemak dan minyak dalam tempat yang dingin dan gelap, dan oksidasi dapat dicegah dengan menggunakan bahan-bahan antioksidan yang mengandung vitamin $\mathrm{E}$, salah satunya adalah penggunaan wortel terhadap bahan pangan.

Parameter rasa nugget ayam dengan penambahan wortel tidak ada perbedaan kesukaan oleh panelis. Ini karena pada daging ayam beserta bumbu-bumbu yang digunakan dalam pembuatan nugget ayam wortel memiliki rasa yang lebih dominan. Hal ini didukung penelitian Bhosale etal.(2011) bahwa tidak ada perbedaan kesukaan signifikan antara parameter rasa tanpa penambahan wortel dan dengan penambahan wortel. Hal ini juga karena daging ayam dan bumbu-bumbu sudah memiliki rasa yang gurih sehingga penambahan wortel belum bisa mendominasi rasa nugget ayam.

Berdasarkan kajian yang dilakukan oleh peneliti, pada parameter tekstur nugget ayam dengan penambahan wortel memiliki tekstur yang lebih lembut dan lebih bervolume daripada tanpa penambahan wortel. Pada dasarnya wortel memiliki tekstur yang renyah karena tingginya kadar air, dengan adanya teknik blanching maka tekstur wortel menjadi lembut karena berkurangnya kadar air akibat pemanasan. Menurut Muchtadi dan Sugiyono (2014) blanching merupakan proses pemanasan suatu bahan pangan menggunakan teknik uap atau air panas pada suhu kurang dari $100^{\circ} \mathrm{C}$.

Setelah itu dilanjutkan dengan uji indeks efektivitas de Garmo untuk mengetahui tingkat perlakuan terbaik di antara perlakuan. Hasil uji lanjutan dapat dilihat pada Tabel 2.

Tabel 2. Hasil uji indeks efektivitas De Garmo

\begin{tabular}{lcccccc}
\hline \multirow{2}{*}{$\begin{array}{c}\text { Parameter } \\
\text { organoleptik }\end{array}$} & \multicolumn{3}{c}{ Nilai Efektivitas } & \multicolumn{3}{c}{ Nilai Produk } \\
\cline { 2 - 7 } \multicolumn{1}{l}{ Warna } & P1 & P2 & P3 & P1 & P2 & P3 \\
Bau & 0,0 & 1 & 0,77 & 0,0 & 0,26 & 0,20 \\
Rasa & 0,0 & 1 & 1 & 0,0 & 0,23 & 0,23 \\
Tekstur & 0,0 & 0,26 & 1 & 0,0 & 0,05 & 0,21 \\
Total & 0,0 & 0,6 & 1 & 0,0 & 0,17 & 0,29 \\
\hline
\end{tabular}

Berdasarkan Tabel 2, parameter warna, nilai produk (NP) tertinggi berada pada P2 yaitu o,26. Nilai produk (NP) pada parameter bau tertinggi berada pada pelakuan 2 dan 3 dengan nilai o,23. Nilai produk (NP) pada parameter rasa tertinggi berada pada perlakuan ketiga yaitu 0,21 dan parameter rasa nilai produk (NP) tertinggi berada pada perlakuan ketiga yaitu 0,29. Total nilai produk (NP) tertinggi yaitu pada perlakuan ketiga dengan penambahan wortel $35 \%$ pada 320 g ayam.

\section{SIMPULAN}

Hasil penelitian menunjukkan terdapat perbedaan nyata pengaruh persentase penambahan wortel terhadap tingkat kesukaan warna, bau dan terkstur nugget ayam yang dihasilkan. Tidak terdapat perbedaan nyata pengaruh persentase penambahan wortel terhadap tingkat kesukaan rasa nugget ayam. Sehingga dapat disimpulkan bahwa penambahan wortel sampai $35 \%$ dalam pembuatan nugget ayam masih bisa diterima atau disukai konsumen.

\section{UCAPAN TERIMAKASIH}

Terimakasih kepada Dinas Peternakan Kabupaten Bondowoso, PPL Kecamatan Binakal, KWT Sejahtera, Panelis, dan semua pihak yang telah berperan dalam penelitian ini.

\section{DAFTAR PUSTAKA}

Bhosale S. S., Biswas A. K., Sahoo J., Chatli M. K., Sharma D. K., and Sikka S. S. 2011. Quality Evaluation of Functional Chicken Nuggets Incorporated with 
Ground Carrot and Mashed Sweet Potato. Food Science and Technology International. Food Science and Technology international. 17(3): 0233-7. http:// fst.sagepub.com/. (01 Juli 2020).

Depkes RI. 2017. Mari sukseskan Gerakan "Germas" dan "Ayo Makan Sayur dan Buah”. https://kelsawojajar. malangkota.go.id/mari-sukseskan-gerakangermas-dan-ayo-makan-sayur-dan-buah/, diakses tgl 18 Juli 2020.

Gaman P. M., dan Sherrington K. B. 1992. Ilmu Pangan Pengantar Ilmu Pangan, Nutrisi dan Mikrobiologi Ed. 2nd. Yogyakarta: Gadjah Mada University Press.

Harjanto, D. 2006. Kualitas Kimia Daging Dada Ayam Broiler yang Pakannya Ditambahkan Campuran Minyak Ikan Kaya Asam Lemak Omega-3. Bogor: Program Studi Teknologi Hasil Ternak Fakultas Peternakan Institut Pertanian Bogor
Lestari, D. W., Widati, A. S., dan Widyastuti, E. S. 2013. Pengaruh Substitusi Tepung Tapioka Terhadap Tekstur dan Nilai Organoleptik Dodol Susu. Jurnal FAPET UB.

Litbang Pertanian. 2017. Indonesia Menuju Swasembada Protein Hewani. http://www.litbang.pertanian. go.id/info-aktual/2826/, diakses tgl 30 Juli 2020.

Muchtadi, T. R., dan Sugiyono. 2014. Prinsip Proses dan Teknologi Pangan. Alfabeta. Bandung

Utami, S. S., Guntoro, Suharianto, dan Umami, M. R. 2018. Sifat Fisik dan Sensori Nugget Wortel Brokoli. Seminar nasiona hasil penelitian dan pengabdian masyarakat. Politeknik Negeri Jember.

Widiarti, W., dan Santosa, T. H. 2017. Model Diversifikasi Konsumsi Pangan bagi Masyarakat Pinggiran Hutan Berbasis Sumberdaya Lokal dan Teknologi. Agritrop Jurnal Ilmu-Ilmu Pertanian, Universitas Muhammadiyan Jember. 